\title{
Analysis of Infiltration Well Dimensional in Kedungkandang District, Malang City, Indonesia
}

\author{
Azarine Nabila Jifa ${ }^{1}$, Arief Rachmansyah ${ }^{2}$, Aminudin Afandhi ${ }^{3}$ \\ ${ }^{1}$ Post Graduate School of Environmental and Development, Brawijaya University, Malang, Indonesia \\ ${ }^{2}$ Civil Engineering Department, Faculty of Engineering, Brawijaya University, Malang, Indonesia \\ ${ }^{3}$ Pest and Plant Disease Department, Faculty of Agriculture, Brawijaya University, Malang, Indonesia
}

\begin{abstract}
Kedungkandang District is one of the fastest growing areas in Malang City and become a urban area. The implication this development is dcreasing of urban open space area by $1-2 \%$ per year, and followed by increased surface flow during rain. Infiltration well is one of the efficient rainwater utilization to reduce run-off. In Kedungkandang district three are different soil types which affects the permeability coefficient value for determination the dimension of infiltration well. This study aimed to determine the dimension of infiltration wells suitable for application individual infiltration wells for housing type $36,45,54,70,90$ and 110 . In order to determine dimension of infiltration wells would be used, there were some analysis done: hydrology and soil permeability coefficient. The conclusion from this research was the bigger the house size, it would need a bigger dimension of infiltration well as well. From the three types of soil in Kedungkandang, the houses in alluvial fan ground type and tuff volcanic soil require a smaller size of infiltration wells than the houses located in Buring volcano mountain sediments.
\end{abstract}

Key words: infiltration well, run-off

\section{INTRODUCTION}

Changes in land use due to increased urbanization and development have a significant impact on hydrological processes [1], [2]. Land with $30-50 \%$ impervious surface can infiltrates into the aquifer $15-20 \%$ runoff. Land with $75 \%$ $100 \%$ impervious surface can infiltrates into the aquifer only $5-10 \%$, over one half becomes srface run-off [3]. So it is not enough to do the drainage channel development only, because the drainage channel is only able to drain and divert rainwater runoff [4].

There is a need to increase absorbing areas to resolve flooding and inundation problems in urban areas [5]. If there is absorbing area provided , urban run-off will decrease and restore the stability of the hydrological process [5]. Infiltration well is one of the most efficient methods of efficient rainwater absorption capable to disentangle urban run-offs[6].

Infiltration well is one of the rainwater utilization efforts by absorbing rainwater into the soil. A deliberate hole is made on the ground to

Correspondence address:

Azarine Nabila Jifa

Email : azarinejifa@ymail.com

Alamat : Master Program of Environmental Resources

Management and Development,

Brawijaya University accommodate and absorb rainwater [7]. The efficiency of infiltration well is influenced by the model and dimensions of infiltration well [7]. That's why an analysis to determine the model and dimension of infiltration well is needed.

Kedungkandang District is one of the areas with rapid development in Malang. This is proven by the decrease of open land such as rice field and dry field by $1-2 \%$ every year. It's getting worse because of population growth by 1,16\% from 2014 to 2015 [8]. Based on the facts, it causes Kedungkandang to be one of the areas which is vulnerable to flooding and inundation.

Kedungkandang district has different environmental and geological conditions. There are three different soil types: buring volcano mountain sediments, alluvial fans and tuff volcanic sediments. Each type of soil has different characteristics [9]. Meanwhile, to determine the dimension of infiltration well is influenced by soil permeability coefficient [7].

The aimed of study is to determine the dimension of infiltration wells suitable for application in Kedungkandang with different types of soil. The infiltration wells determined were individual wells for houses by type 36,45 , 54, 70, 90 and 110. 


\section{STUDY AREA}

Kedungkandang District is located in the east and southeast of Malang City. Geographically, Kedungkandang District is located between $122^{\circ} 36^{\prime} 144$ "up to $122^{\circ} 40^{\prime} 42^{\prime \prime}$ East Longitude and $007^{\circ} 36^{\prime} 38$ "up to $008^{\circ} 01^{\prime} 57^{\prime \prime}$ South Latitude. The area of Kedungkandang District is $39.89 \mathrm{~km} 2$ or about $3989 \mathrm{Ha}$.

Based on the geological map of the Environment Agency of Malang City, in Kedungkandang District there are three rock formation: tuff / volcanic sediments, alluvial fans and Buring volcanic rock. The weathering of those rock types produce three different kinds of soil. Soil sampling for laboratory test and field permeability tests ware performed randomly, because it's considered as having similar soil characteristics.

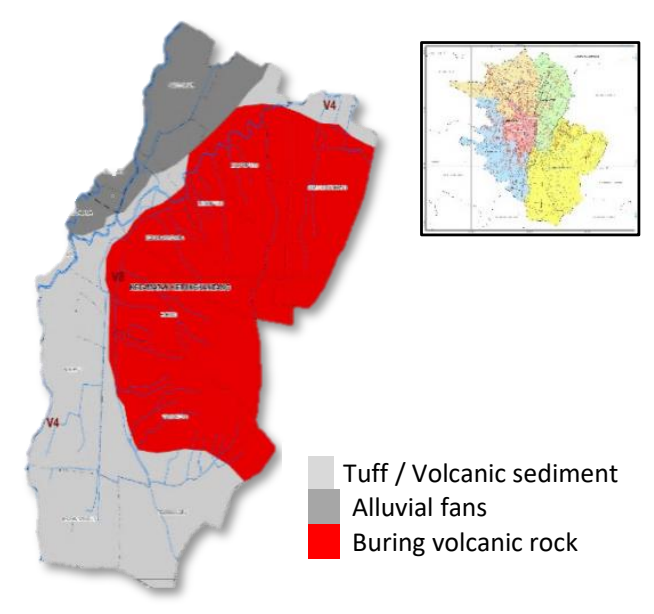

Picture 1. Geological Condition of Kedungkandang District

\section{RESEARCH METHOD}

This research was considered as quantitative research because it emphasized on the aspects of objective measurements on the phenomenon that occurs i.e flooding and inundation that occurred in Kedungkandang District, Malang City.

\section{Data Collection}

The data needed in this research were primer data and secondary data. Primary data is data obtained by direct measurement in the field. The primary data consists of infiltration rate to determine the permeability coefficient value. Secondary data is data obtained from library study. The secondary data were rainfall data obtained from year 2007 - 2016, Kedungkandang District administrative map, and geological map of Kedungkandang District.

\section{Data Analysis}

The analysis conducted in this research were hydrological analysis and permeability coefficient analysis and infiltration well model analysis. Stages of analysis performed were as follows:

1. Analysis of rainfall distribution, on the analysis of the rainfall distribution of the method area is done by fixed method because the number of measurement post is only available in one station[4].

2. Test consistency of rainfall data using RAPS (Rescaled Adjusred Partial Sums) method. This method was chosen because the number of rain stations used was only one station [4].

3. Outlier test of rainfall data by comparing the maximum and minimum value of data whether it was feasible to use or not [4].

4. Rainfall frequency analysis was done by using three methods, which are normal distribution method, Gumbel method and Log Pearson III method. The results of the three methods were tested by testing Smirnov-kolmogorov and Chi-Square test [4].

5. Analysis of rainfall intensity using Mononabe method [4]:

$$
I=\frac{R_{24}}{24}\left[\frac{24}{t}\right]^{2 / 3}
$$

Where $\mathrm{I}$ is the rain intensity $(\mathrm{mm} / \mathrm{h}) ; \mathrm{T}$ is the time or duration of rain (hours) and $R_{24}$ is the maximum rainfall in a day $(\mathrm{mm})$.

6. Determination of the run-off coefficient, based on the Water Flow Coefficient Table, the run-off coefficient value used was 0.75-0.95 [4].

7. Determine the tributary area [10].

8. Analyze the discharge of rainwater runoff using Rational method [10]:

$$
\mathbf{Q}=\mathbf{C} \mid \mathbf{A}
$$

Where $Q$ is the rainwater discharge $(\mathrm{m} 3 / \mathrm{s}) ; \mathrm{C}$ is the jetting coefficient; $I$ is the intensity of rainfall $(\mathrm{m} / \mathrm{s})$ and $\mathrm{A}$ is tributary area $\left(\mathrm{m}^{2}\right)$.

9. The permeability coefficient analysis begins by calculating the infiltration rate of the field, then calculating the infiltration rate by the horton method [11]:

$f=f_{c}+\left(f_{0}-f_{c}\right) e^{-K t}$

Where $f$ is the infiltration capacity at a given time $(t), f c$ is the infiltration capacity when it reaches a constant condition, fo is the initial infiltration capacity, $\mathrm{K}$ is the Horton's constant which represents the rate of decreasing infiltration capacity and $\mathrm{t}$ is the time in hours.

10. Analysis of infiltration well model using Sunjoto method [12]: 
$H=\frac{Q}{F K}\left\{1-\exp \left(\frac{-F K T}{\pi R^{2}}\right)\right\}$

Where $\mathrm{H}$ is the water level in the well ;; $\mathrm{Q}$ is the debit of water discharge; $F$ is the geometric factor of the circle; $K$ is the coefficient of soil permeability; $T$ is the dominant duration of rain; $R$ is the radius of the well.

\section{RESULT AND DISCUSSION}

Distribution of Rainfall

The choice of the method of distribution of rainfall area divided into two kinds: first, the selection of method based on the extent of the drainage basin or the area of study area and second, based on the number of rain measurement post located in the study area [5]. If the research were to follow the first method based on the area of study, then the chosen method is the method of algebra because the area of Kedungkandang District is $38,89 \mathrm{~km}^{2}$. The algebraic method is chosen if the study area is less than $500 \mathrm{~km}^{2} 500 \mathrm{~km} 2$ and the number of measurement post is more than one. However, in the reality it turned out that the number of rain measurement post is only one available in Kedungkandang Rain Station. Then the rainfall distribution method chosen was the fixed method. Maximum daily rainfall recorded at Kedungkandang Station can be seen in Table 1.

Tabel 1. Maximum Daily Rainfall Kedungkandang Station

\begin{tabular}{cc}
\hline Year & Rainfall Intensity $(\mathbf{m m})$ \\
\hline 2007 & 125,00 \\
2008 & 145,00 \\
2009 & 85,00 \\
2010 & 125,00 \\
2011 & 91,00 \\
2012 & 87,00 \\
2013 & 102,00 \\
2014 & 103,00 \\
2015 & 110,00 \\
2016 & 88,00 \\
\hline
\end{tabular}

Source: UPT Sumber Daya Air Bango Gedangan

\section{Consistency Test}

The data consistency test served in order to test the equipment and data. The RAPS test was performed using the cumulative test of the mean deviation divided by the cumulative roots of the mean deviation from the mean value. Then the result was compared to the $\mathrm{Q} / \mathrm{n}^{0,5}$ and $\mathrm{R} / \mathrm{n}^{0,5}$ table. The data could be accepted if $Q / n^{0,5}$ and $R / n^{0,5}$ value is much smaller than $Q / n^{0,5}$ and $R / n^{0,5}$ table. From the calculation with probability $99 \%$ the result was $\mathrm{Q} / \mathrm{n}^{0,5}$ and $\mathrm{R} / \mathrm{n}^{0,5}$ which was smaller than $Q / n^{0,5}$ and $R / n^{0,5}$ tabel so the conclusion was the data was acceptable.

\section{Outlier Test}

Outlier test was used in order to analyze the maximum and minimum values of the data and whether the data are possible to be analyzed or not. The data are deemed possible to be used for further analysis if the maximum and minimum values of the data are still within the range of their threshold values. The result from this analysis shows that the maximum threshold value is 151,506 and the maximum value of the data is 145 , while the minimum threshold value is 72,055 and the minimum value of the data is 88 . Based on this result, the data gained in this research can be used for further analysis.

\section{Frequency of Rainfall}

This analysis was used in order to gain the design rainfall value with certain return period. The return period used in this research was 25 years. There were three methods used such as normal distribution method, Gumble method and Log Pearson III method. After the design rainfall value has been gained, the result will then be analyzed further using Smirnov-Kolmogorov test and Chi-Square test. Smirnov-Kolmogorov test is used by comparing the maximum delta value with its critical delta value. The data were deemed feasible for further research if the maximum delta value is bigger than its critical delta value and if the maximum delta value is smaller than its critical delta value the data will be deemed as not feasible for further research. As for the Chi Square test is done by comparing the $\mathrm{X}^{2}$ value with its critical $\mathrm{X}^{2}$ value. The data were deemed feasible for further research if the $X^{2}$ value is smaller than its critical $X^{2}$ value and if the $X^{2}$ value is bigger than its critical $X^{2}$ value the data will be deemed as not feasible for further research. The result of this analysis shows that the data feasible for further research are the data gained from Log-Pearson III method. The result of frequency analysis and testing can be seen on Table 2 and Table 3.

Table 2 Chi-Square Test Result

\begin{tabular}{ccccc}
\hline$\alpha$ & $X^{2}$ & Normal & $\begin{array}{c}\text { Gumbel } \\
\text { Method }\end{array}$ & $\begin{array}{c}\text { Log Pearson } \\
\text { III Method }\end{array}$ \\
\hline $\begin{array}{c}1 \% \\
\text { Result }\end{array}$ & 6,635 & $\begin{array}{c}3,827 \\
\text { Accepted }\end{array}$ & $\begin{array}{c}8,891 \\
\text { Declined }\end{array}$ & $\begin{array}{c}5,515 \\
\text { Accepted }\end{array}$ \\
\hline
\end{tabular}

Source: Analysis Result, 2017

\section{Intensity of Rainfall}

Rainfall intensity value is gained by using the values gained from the Log Pearson III method. The method used for this analysis is Mononobe method. The result of rain intensity calculation can be seen on Table 4. 
Table 3 Smirnov-Kolmogorov Test Result

\begin{tabular}{ccccc}
\hline $\begin{array}{l}\text { Return } \\
\text { Period }\end{array}$ & $\mathrm{t}$ & $\begin{array}{c}\text { Normal } \\
\text { Metod }\end{array}$ & $\begin{array}{c}\text { Gumbel } \\
\text { Method }\end{array}$ & $\begin{array}{c}\text { Log } \\
\text { Pearson III } \\
\text { Method }\end{array}$ \\
\hline 25 & 1,6400 & 139,059 & 163,312 & 144,333 \\
50 & 2,0500 & 147,298 & 178,198 & 152,833 \\
100 & 2,3300 & 152,925 & 192,974 & 160,965 \\
\hline Maximum Delta & 0,64 & 0,14 & 0,132 \\
\hline \multicolumn{2}{l}{ Critical Delta } & 0,368 & 0,368 & 0,368 \\
\hline \multicolumn{2}{l}{ Result } & Declined & Accepted & Accepted \\
\hline
\end{tabular}

Source: Analysis Result, 2017

Tabel 4. Rain Intensity Analysis Result

\begin{tabular}{cc}
\hline Time (minute) & Return Period 25 Years \\
\hline 1 & 50,036 \\
2 & 31,521 \\
3 & 24,055 \\
4 & 19,857 \\
5 & 17,112 \\
10 & 10,780 \\
20 & 6,791 \\
30 & 5,182 \\
60 & 3,265 \\
120 & 2,057 \\
180 & 1,570 \\
240 & 1,296 \\
\hline
\end{tabular}

Source: Analysis Result, 2017

Based on table 4, if the rain duration in Sawojajar Region is 2 hours or 120 minutes, the rain intensity will be $2,057 \mathrm{~mm} /$ minute atau $3,428 \cdot 10^{-5} \mathrm{~m} / \mathrm{s}$. After the infiltration value has been gained, the next step is making the IDF (Intensity-Duration Frequency) curve. From the IDF curve (Picture 1) it can be concluded that the longer the rain duration, the intensity of the rain will be smaller.

Table 5 Roof Measurement Result

\begin{tabular}{cccccc}
\hline $\begin{array}{c}\mathbf{a} \\
\left(\mathbf{m}^{2}\right)\end{array}$ & $\begin{array}{c}\mathbf{p} \\
(\mathbf{m})\end{array}$ & $\begin{array}{c}\mathbf{I} \\
(\mathbf{m})\end{array}$ & $\begin{array}{c}\mathbf{P} \\
(\mathbf{m})\end{array}$ & $\begin{array}{c}\mathbf{L} \\
(\mathbf{m})\end{array}$ & $\begin{array}{c}\mathbf{A} \\
\left(\mathbf{m}^{\mathbf{2}}\right)\end{array}$ \\
\hline 36 & 6 & 6 & 8 & 8 & 64 \\
\hline 45 & 6 & 7,5 & 8 & 9,5 & 76 \\
\hline 54 & 6 & 9 & 8 & 11 & 88 \\
\hline 70 & 7 & 10 & 9 & 12 & 108 \\
\hline 90 & 6 & 15 & 8 & 17 & 136 \\
\hline 110 & 10 & 11 & 12 & 13 & 156 \\
\hline
\end{tabular}

Source: Analysis Result, 2017

Explanation: A represents house size, $P$ is the length of the house, $L$ is the width of the house, $p$ is the length of the roof, $I$ is the width of the roof, and $A$ is the measurement of the roof area.

\section{Coefficient of Run off}

The flow coefficient value of a certain region consists of various usage of the field within the region can be searched by calculating the average values of each usage of the field. In this research, the usage of field analyzed is the usage of roofs. Based on the Flow Coefficient Table, the coefficient value for roof is 0,75-0,95.

\section{Volume of Rainwater}

The area used for the measurement of rain flow area is the roof area from various type of houses. The type of houses used are type 36, type 45 , type 54, type 70, type 90 and type 110.

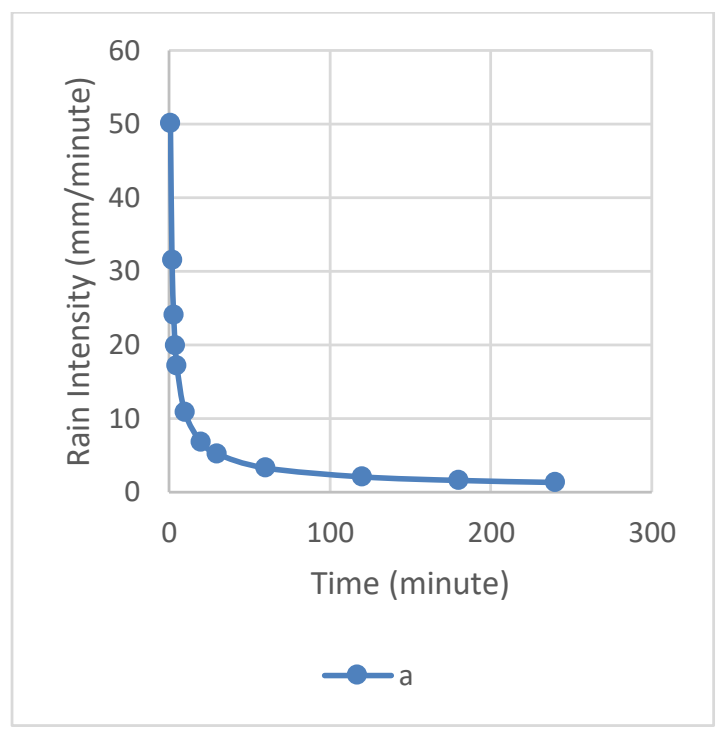

Picture 1. Intensity-Duration Frequency Curve

\section{Debit of Runoff}

After the rain intensity value, coefficient value and rain flow area have been gained, the rainfall runoff debit is calculated by using rational formula.

Table 6 Result of The Rain Runoff Debit Measurement

\begin{tabular}{cccc}
\hline $\begin{array}{c}\mathbf{A} \\
\left(\mathbf{c m}^{2}\right)\end{array}$ & $\mathbf{C}$ & $\begin{array}{c}\mathbf{I} \\
(\mathbf{c m} / \mathbf{s})\end{array}$ & $\begin{array}{c}\mathbf{Q} \\
\left(\mathbf{c m}^{3} / \mathbf{s}\right)\end{array}$ \\
\hline 640000 & 0,95 & 0,0034 & 2084,14 \\
\hline 760000 & 0,95 & 0,0034 & 2474,92 \\
\hline 880000 & 0,95 & 0,0034 & 2865,70 \\
\hline 1080000 & 0,95 & 0,0034 & 3516,99 \\
\hline 1360000 & 0,95 & 0,0034 & 4428,80 \\
\hline 1560000 & 0,95 & 0,0034 & 5080,10 \\
\hline
\end{tabular}

Source: Analysis Result, 2017

Explanation: $\mathrm{A}$ is the tributary area, $\mathrm{C}$ is the flow coefficient value, $I$ is the rain intencity dan $Q$ is the rainfall runoff debit value. 


\begin{tabular}{|c|c|c|c|c|c|c|c|}
\hline \multicolumn{8}{|c|}{ Return Period 25} \\
\hline \multicolumn{8}{|c|}{ Rain Intensity $=0,0034 \mathrm{~cm} / \mathrm{s}$} \\
\hline \multicolumn{8}{|c|}{ Soil Type = Buring Volcano } \\
\hline $\begin{array}{l}\text { House } \\
\text { size }\end{array}$ & $\begin{array}{c}\text { Roof Area } \\
\left(\mathrm{cm}^{2)}\right.\end{array}$ & $\begin{array}{c}\text { Permeability } \\
\text { Measurement } \\
(\mathrm{cm} / \mathrm{s})\end{array}$ & $\begin{array}{c}\text { Rain } \\
\text { Duration (s) }\end{array}$ & $\begin{array}{l}\text { Runoff Debit } \\
\left(\mathrm{cm}^{3} / \mathrm{s}\right)\end{array}$ & $\begin{array}{l}\text { Geometric } \\
\text { factor }(\mathrm{cm})\end{array}$ & $\begin{array}{l}\text { Radius } \\
(\mathrm{cm})\end{array}$ & Depth $(\mathrm{cm})$ \\
\hline 36 & 640000 & 0,0007218 & 7200 & 2084,14 & 275 & 50 & 1747,66 \\
\hline 45 & 760000 & 0,0007218 & 7200 & 2474,92 & 275 & 50 & 2075,34 \\
\hline 54 & 880000 & 0,0007218 & 7200 & 2865,70 & 275 & 50 & 2403,03 \\
\hline 70 & 1080000 & 0,0007218 & 7200 & 3516,99 & 412,5 & 75 & 1350,09 \\
\hline 90 & 1360000 & 0,0007218 & 7200 & 4428,80 & 412,5 & 75 & 1700,11 \\
\hline 110 & 1560000 & 0,0007218 & 7200 & 5080,10 & 412,5 & 75 & 1950,13 \\
\hline \multicolumn{8}{|c|}{ Soil Type = Kipas Alluvial } \\
\hline $\begin{array}{l}\text { House } \\
\text { size }\end{array}$ & $\begin{array}{l}\text { Roof Area } \\
\left(\mathrm{cm}^{2)}\right.\end{array}$ & $\begin{array}{l}\text { Permeability } \\
\text { Measurement } \\
(\mathrm{cm} / \mathrm{s})\end{array}$ & $\begin{array}{c}\text { Rain } \\
\text { Duration (s) }\end{array}$ & $\begin{array}{l}\text { Runoff Debit } \\
\left(\mathrm{cm}^{3} / \mathrm{s}\right)\end{array}$ & $\begin{array}{l}\text { Geometric } \\
\text { factor }(\mathrm{cm})\end{array}$ & $\begin{array}{l}\text { Radius } \\
(\mathrm{cm})\end{array}$ & Depth $(\mathrm{cm})$ \\
\hline 36 & 640000 & 0,0165619 & 7200 & 2084,14 & 275 & 50 & 450,58 \\
\hline 45 & 760000 & 0,0165619 & 7200 & 2474,92 & 275 & 50 & 535,06 \\
\hline 54 & 880000 & 0,0165619 & 7200 & 2865,70 & 275 & 50 & 619,55 \\
\hline 70 & 1080000 & 0,0165619 & 7200 & 3516,99 & 412,5 & 75 & 483,02 \\
\hline 90 & 1360000 & 0,0165619 & 7200 & 4428,80 & 412,5 & 75 & 608,25 \\
\hline 110 & 1560000 & 0,0165619 & 7200 & 5080,10 & 412,5 & 75 & 697,69 \\
\hline \multicolumn{8}{|c|}{ Soil Type = Vulcanic Tuff Cediments } \\
\hline $\begin{array}{l}\text { House } \\
\text { size }\end{array}$ & $\begin{array}{l}\text { Roof Area } \\
\left(\mathrm{cm}^{2)}\right.\end{array}$ & $\begin{array}{c}\text { Permeability } \\
\text { Measurement } \\
(\mathrm{cm} / \mathrm{s})\end{array}$ & $\begin{array}{c}\text { Rain } \\
\text { Duration (s) }\end{array}$ & $\begin{array}{l}\text { Runoff Debit } \\
\left(\mathrm{cm}^{3} / \mathrm{s}\right)\end{array}$ & $\begin{array}{l}\text { Geometric } \\
\text { factor }(\mathrm{cm})\end{array}$ & $\begin{array}{l}\text { Radius } \\
(\mathrm{cm})\end{array}$ & Depth $(\mathrm{cm})$ \\
\hline 36 & 640000 & 0,016965 & 7200 & 2084,14 & 275 & 50 & 440,53 \\
\hline 45 & 760000 & 0,016965 & 7200 & 2474,92 & 275 & 50 & 523,13 \\
\hline 54 & 880000 & 0,016965 & 7200 & 2865,70 & 275 & 50 & 605,72 \\
\hline 70 & 1080000 & 0,016965 & 7200 & 3516,99 & 412,5 & 75 & 473,57 \\
\hline 90 & 1360000 & 0,016965 & 7200 & 4428,80 & 412,5 & 75 & 596,34 \\
\hline 110 & 1560000 & 0,016965 & 7200 & 5080,10 & 412,5 & 75 & 684,04 \\
\hline
\end{tabular}

\section{Permeability Coefficient nof Soil}

The soil permeability coefficient value was gained by doing field research using infiltrometer single ring. The data gained from this field research is the field infiltration rate that will be analyzed using Horton method.

The Horton infiltration value is described as a curve that will always declined along with the increase of time. the data needed to get the Horton infiltration value are $f_{0}$ value which is the infiltration value at the beginning, $f_{c}$ which is the constant infiltration value and $k$ value. In this research, the analysis process was done using Ms. Excel program. The result of the $f_{0}, f_{c}$ and $k$ values can be seen on the table 7 below.

Table 7. $f_{0}, f_{c}$ and $k$ Values

\begin{tabular}{lcccc}
\hline \multicolumn{1}{c}{ Soil Type } & Type & $\mathbf{k}$ & $\mathbf{f}_{\mathbf{0}}$ & $\mathbf{f}_{\mathbf{c}}$ \\
\hline Volcanic tuff & A & 4,072 & 8,000 & 0,025 \\
sediments & & & & \\
$\begin{array}{l}\text { Alluvial fans } \\
\text { Buring volcano }\end{array}$ & B & 2,371 & 9,167 & 0,325 \\
mountain & C & 2,217 & 5,000 & 0,217 \\
sediments & & & & \\
\hline
\end{tabular}

Source: Analysis Result, 2017
This result concludes that the faster the infiltration process is at the beginning, more speed will be reduced after some times and the soil will be constant and saturated.

If three types of soils in Kedungkandang region are compared, based on picture 5.3, the type of soil which has the biggest infiltration value is the B type which is Kipas alluvial soil while the soil which has the smallest value is the A type soil or the cediments from Buring volcano mountain.

\section{Dimension of Infiltration Well}

The infiltration well model used in this research is the circular sectioned empty well model. This model was chosen because this research needs an individual infiltration well so the researcher chose the easiest model to be applied. The material used for the wall of the infiltration well is a pipe shaped concrete. The dimension of the infiltration well can be seen on table 8. 


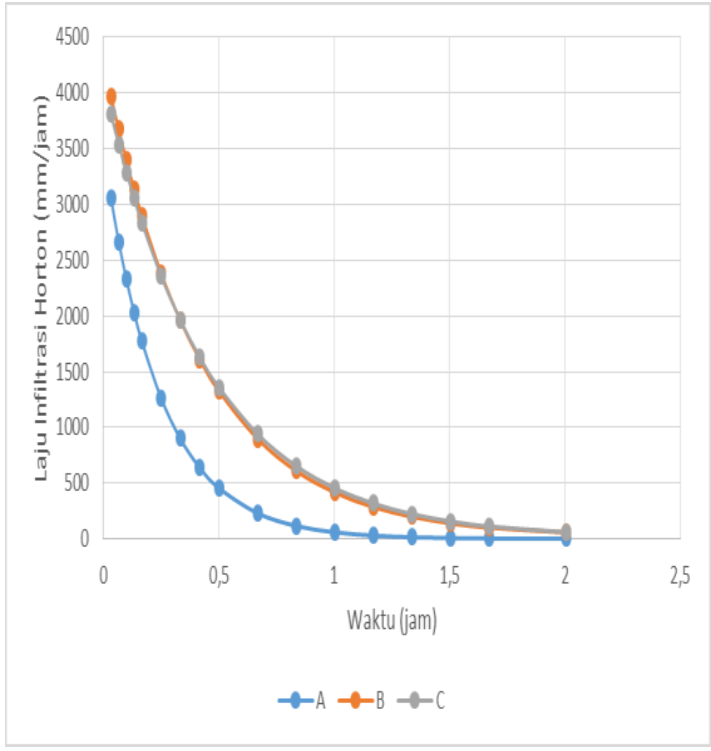

Picture 2. Horton Infiltration Rate Curve

The calculation result showed that the dimension of the infiltration well for the smallest house which is $36 \mathrm{~m}^{2}$ is within $20 \mathrm{~cm}$ diameter and $0,999 \mathrm{~m}$ or $1 \mathrm{~m}$ depth. If the infiltration well is made from piped shaped concrete with $20 \mathrm{~cm}$ diameter, then it will only need 1 pipe shaped concrete. The result of the calculation of pipe shaped concrete needed for each house size and soil type can be seen on table 8 below.

\section{CONCLUSION}

The conclusion that can be taken from this research is that the bigger type of house is, the dimension of the infiltration well needed will be bigger as well. The absorbent well diameter for 36 , 45 and 54 houses is 1 meter and diameter of absorbent wells for house 70,90 and 110 is 1.5 meters. The depth of absorption wells that resulted from the calculation that is on soil type of volcanic buring volcanic sediment obtained the depth of absorbent wells for house size 36 is 17,48 m; For house size 45 is 20.75 m; For type 54 houses is $24.03 \mathrm{~m}$; For house size 70 is $13.50 \mathrm{~m}$; For house size 90 is $17 \mathrm{~m}$; For type 110 houses is $19.50 \mathrm{~m}$. In the alluvial fan soil type, the depth of the infiltration wells for type 36 house is $4.51 \mathrm{~m}$; For type 45 homes is $5.35 \mathrm{~m}$; For type 54 houses is $6.20 \mathrm{~m}$; For type 70 homes is $4.83 \mathrm{~m}$; For home type 90 is $6.08 \mathrm{~m}$; For type 110 houses is $6.98 \mathrm{~m}$. In the soil type of volcanic tuff sediment, the depth of absorbent wells for type 36 house is 4.41 $\mathrm{m}$; For the type 45 house is $5.23 \mathrm{~m}$; For type 54 housing is $6.06 \mathrm{~m}$; For house size 70 is $4.74 \mathrm{~m}$; For home type 90 is $5.96 \mathrm{~m}$; For type 110 houses is $6.84 \mathrm{~m}$

\section{REFERENCES}

[1]. Baek, S.S., Choi D.H., Jung J.W., Lee H.J., Lee H., Yoon K.S., Cho K.H. 2015. Optimizing Low Impact Development (LID) for stormwater runoff treatment in urban area: Experimental and modeling approach. Water Research 86: 122-131

[2]. DeFries, R., Eshleman, N.K. 2004. Land-Use change and hydrologic proceses a major focus of the future. Hydrol. Process.18 (11)

[3]. Ruby, E. 2006. How Urbanization Affect the Water Cycle. California: CA WALUP

[4]. Suripin. 2004. Sistem Drainase Perkotaan Yang Berkelanjutan . Yogyakarta: Penerbit Andi

[5]. Elga, S., Bronders J., Batelaan O. 2015. Hydrological Modelling of Urbanized Catchment: A Review and Futur Directions. Journal of Hydrology 529 : 62-81

[6]. Ardiyana, M., Mohammad B., Sumiadi. 2016. Studi Penerapan Ecodrain Pada Sistem Drainase Perkotaan (Studi Kasus: Perumahan Sawojajar Kota Malang). Jurnal Teknik Pengairan (7) 2: 295-309

[7]. Kusnaedi. 2011. Sumur Resapan Untuk Pemukiman Perkotaan dan Pedesaan. Jakarta: Penebar Swadaya

[8]. Badan Pusat Statistik. 2016. Kedungkandang Dalam Angka 2016. Malang: Badan Pusat Statistik

[9]. Elhakim, A.F. 2016. Estimation of Soil Permeability. Alexandria Engineering Journal 55: 2631 - 2638

[10]. Urban Drainage Flood Control. 2017. Urban Storm Drainage Criteria Manual Volume 1. Colorado : UDFC

[11]. Chahinian, N., Moussa, R., Andrieux, P., Voltz, Marc. 2005. Comparison of Infiltration Models to Simulate Flood Events at the Field Scale. Journal of Hydrology 306: 191-214

[12]. Sunjoto. 2011. Teknik Drainase Pro-Air. Yogyakarta: Universitas Gadjah Mada 